\title{
The Correlation Between Attitudes Toward HIV/AIDS Transmission Through the Use of Syringes and the Type of Dropout Among the Participants of Methadone Maintenance Treatment
}

\author{
Risnawati $^{1}$ \\ ${ }^{1}$ Ar-Rum Health \\ Sciences College Salatiga \\ Salatiga, Central Java \\ risnaakbidarrum@gmail.com \\ Muchlis AU Sofro ${ }^{4}$ \\ ${ }^{4}$ Dr. Kariadi Central Hospital Semarang \\ Semarang, Central Java \\ Muchlis.aus@gmail.com \\ Dendi Durahman ${ }^{7}$ \\ ${ }^{7}$ Salatiga Regional General Hospital \\ Salatiga, Central Java \\ dendimawar@gmail.com
}

\author{
Bagoes Widjanarko ${ }^{2}$ \\ ${ }^{2}$ Diponegoro University \\ Semarang, Central Java \\ Bagoes62.@gmail.com \\ Tuti Susilowati ${ }^{5}$ \\ 5Permata Indonesia Health \\ Polytechnic \\ Yogyakarta \\ Iyya.salaman@yahoo.co.id
}

\author{
Zahroh Shaluhiyah ${ }^{3}$ \\ ${ }^{3}$ Diponegoro University \\ Semarang, Central Java
}

\author{
Helmy Apreliasari ${ }^{6}$ \\ ${ }^{6}$ Ar-Rum Health Sciences College \\ Salatiga \\ Salatiga, Central Java \\ helmyaprelia@gmail.com
}

\begin{abstract}
Attitude is one of the factors that influence drop-out behaviour. Attitudes influence behaviour through a careful and reasonable decision making process. In this study, researchers divided the drop-out into 2 types: positive dropout and negative drop-out. It was said positive drop-out if the respondent no longer used any type of drug, while it was said negative drop-out if the respondent still used any type of drug. This study aimed to observe the effect of attitude towards HIV/AIDS transmission through the use of syringes and the type of drop-out among participants of Methadone Maintenance Treatment (MMT). This was a cross-sectional study. Among 69 respondents, most respondents had good attitudes toward HIV/AIDS transmission through the use of syringes of 49 people $(\mathbf{7 2 . 5 \%})$. The mean attitudes score was 18.81 with a mean value of 20.00 . The minimum score was 12, while the maximum score was 23 . The analysis of the correlation between the respondents' attitudes and drop-out
\end{abstract}

among participants of Methadone Maintenance Treatment (MMT) showed that respondents who had positive drop-out among respondents who had good attitudes was $\mathbf{9 8 . 0 \%}$ higher than respondents who had a bad attitude of $57.9 \%$. Based on the results of the multivariate analysis, attitudes toward HIV/AIDS transmission through the use of syringes obtained $O R=20.091$, this meant that a good attitudes toward HIV/AIDS transmission through the use of syringes allowed respondents to have positive drop-out 20.091 times compared to bad attitudes. There was a correlation between respondents' attitudes toward HIV/AIDS transmission through the use of syringes and the type of drop-out among participants of Methadone Maintenance Treatment (MMT) (p-value=0.000).

Keywords: attitudes, HIV/AIDS transmission, dropout, methadone maintenance treatment (MMT) 


\section{INTRODUCTION}

The number of people living with Human Immunodeficiency Virus (HIV) continues to increase. WHO estimated that there were 37,900,000 people living with HIV in 2019. Data in Indonesia showed that by 2019 there were 327,282 HIV cases and one of the groups contributing to HIV cases was injecting drug users. IDUs are very vulnerable to HIV infection, especially those who exchange needles, thus a harm reduction program is needed for IDUs. ${ }^{1-3}$

One example of the harm reduction programs in Indonesia is the Methadone Maintenance Treatment (MMT) which aims to minimize HIV transmission among the IDU population. MMT is an alternative individual treatment, the results of previous studies reported a significant improvement in the quality of life of MMT participants. However, there were some problems in this program, one of which was a high drop-out rate, as shown in a study in Guangdong, China that among 1,512 study participants, $79 \%$ experienced drop-out at the MMT clinic, as well as at the Nguyen MMT Clinic, Thailand which showed that out of 2567 registered patients, 740 patients dropped out of this program. The reasons for the drop-out among MMT participants were a feeling that there was no heroin addiction, conflicts with work, health problems and inability to pay the cost. One factor related to the cause of this drop-out behavior is the attitudes of the IDU. According to Green (1990), a person's behavior is influenced by his attitudes. In this case the dropout behavior of the respondent is influenced by his attitudes toward HIV/AIDS transmission and the correct use of syringe. This is also in line with the theory of reasonable action put forward by Ajzen \& Fishbein (1980) that attitudes influence behavior through a careful and reasoned decision making process. $^{3-9}$

In this study, the writers differentiated drop-out into two types, positive drop-out and negative drop-out. It was said positive dropout if the respondent no longer used any type of drug, while it was said negative drop-out if the respondent still used any type of drug. This study aims to observe the effect of attitudes toward HIV/AIDS transmission through the use of syringes and the type of drop-out among participants of Methadone Maintenance Treatment (MMT).

\section{METHODOLOGY}

The study design was cross sectional. This study was conducted at Methadone Maintenance Clinic at Manahan Community Health Center, Surakarta City. The respondents in this study were IDUs who no longer accessed MMT at Methadone Maintenance Clinic at Manahan Community Health Center Surakarta. The samples used here were in accordance with established criteria. The inclusion criterion was: IDUs who no longer accessed MMT at Methadone Maintenance Clinic at Manahan Community Health Center Surakarta, and the exclusion criteria were: not willing to be a respondent, moved to another city and respondents who could not be called.

In this study, the term dropout is defined as the condition when a participant of Methadone Maintenance Treatment does not take medication for 7 consecutive days without any reason. Theoretically, Methadone Maintenance Treatment (MMT) should last at least 6 months to 2 years or longer. In this study, researchers divided the drop-out into 2 types: positive drop-out and negative drop-out. It was said positive drop-out if the respondent no longer used any type of drug, while it was said negative drop-out if the respondent still used any type of drug. ${ }^{10}$

Data collection was conducted by interviews. Interviews were conducted by researchers and assisted by several enumerators who had been trained before the interview and had the same perception. Before interviewing the respondent, the interviewer first read an explanation so that the respondent understood the study objective. After the explanation was read, the respondent was given an informed consent sheet to be signed when the respondent agreed to become a respondent in this study. Furthermore, this study had obtained information regarding Ethical Clearance from the Health Research Ethics Commission of the Faculty of Public Health, Diponegoro University. From the planned number of samples as many as 75 people, only 69 people that could be interviewed due to several reasons. 4 people moved to another city and 2 people could not be called.

Data analysis was carried out in three stages. The first stage was univariate analysis to explain and describe the number or value of variables with the size of percentage proportion calculated by a predetermined formula. The second stage was bivariate analysis that was performed between independent variables and dependent variable. The relationship between the independent variables and the dependent variable was analyzed using the Chi Square test. The third stage was multivariate analysis using logistic 
negative drop-out were higher among those who had bad

regression analysis to analyze the effect of each independent variable on the dependent variable.

\section{RESULTS}

\section{A. Characteristics of Respondents}

Of the 69 respondents, most of the respondents aged $\geq 32$ years old $(56.5 \%)$, the majority of respondents were male, as many as 68 people $(98.6 \%)$. The majority of respondents were included in the secondary education category as many as 59 people $(85.5 \%)$, and the majority of respondents worked in the formal field as many as 55 people $(84.1 \%)$

\section{B. Respondents' attitudes toward HIV/AIDS transmission through the use of syringes Univariate Analysis}

The results of univariate analysis on respondents' attitudes toward HIV/AIDS transmission through the use of syringes can be seen in Table 1 .

TABLE 1. FREQUENCY DISTRIBUTION OF RESPONDENTS ATTITUDES TOWARD HIV/AIDS TRANSMISSION THROUGH THE USE OF SYRINGES

\begin{tabular}{|l|l|c|c|}
\hline \multirow{2}{*}{ No } & \multirow{2}{*}{ Category } & \multicolumn{2}{|c|}{ Frequency } \\
\cline { 3 - 4 } & & $\mathrm{N}$ & $\%$ \\
\hline 1 & Bad & 19 & 27.5 \\
\hline 2 & Good & 50 & 72.5 \\
\hline \multicolumn{2}{|c|}{ Total } & 69 & 100 \\
\hline \multicolumn{2}{|c|}{ Mean score: 18.81 , Median score: 20.00}
\end{tabular}

Based on table 1, of the 69 respondents most of the respondents had good attitudes towards the transmission of HIV/AIDS through the use of syringes as many as 49 people $(72.5 \%)$. The mean attitudes score was 18.81 with a median score of 20.00 .

\section{Bivariate Analysis}

The correlation between respondents' attitudes and the type of drop-out among the participants of Methadone Maintenance Treatment (MMT) can be seen in table 2 .

Based on Table 2, the analysis results on the relationship between respondents' attitudes and the type of drop-out among the participants of Methadone Maintenance Treatment (MMT) indicated that respondents who had positive drop-out among respondents who had good attitudes was $98.0 \%$ higher than respondents who had bad attitudes of $57.9 \%$. On the other hand, respondents who had attitudes of $42.1 \%$ compared to those who had good attitudes of $2.0 \%$.

TABLE 2. CROSS TABULATION ON THE CORRELATION BETWEEN RESPONDENTS' ATTITUDES AND THE TYPE OF DROP-OUT AMONG THE PARTICIPANTS OF METHADONE MAINTENANCE TREATMENT (MMT)

\begin{tabular}{|l|l|c|c|c|c|c|c|}
\hline \multirow{2}{*}{ No } & \multirow{2}{*}{$\begin{array}{c}\text { Respondent } \\
\text { Attitudes }\end{array}$} & & \multicolumn{4}{|c|}{ Drop-out } & \multicolumn{2}{c|}{ Total } \\
\cline { 3 - 8 } & & \multicolumn{2}{|c|}{ Positive } & \multicolumn{2}{c|}{ Negative } & \multicolumn{2}{c|}{} \\
\cline { 3 - 8 } & & $\mathrm{n}$ & $\%$ & $\mathrm{n}$ & $\%$ & $\mathrm{n}$ & $\%$ \\
\hline 1 & Bad & 11 & 57.9 & 8 & 42.1 & 19 & 100 \\
\hline 2 & Good & 49 & 98.0 & 1 & 2.00 & 50 & 100 \\
\hline
\end{tabular}

Based on the results of statistical tests using the chi square test with a significance level $(\alpha)$ of 0.05 , it was obtained p-value $=0.000$ which meant that there was a correlation between the respondents' attitudes and the type of drop-out among the participants of Methadone Maintenance Treatment (MMT).

\section{Multivariate Modeling Analysis}

Multivariate analysis modeling of multiple logistic regression used the backward wald elimination method. The following table shows the end results of multiple logistic regression analysis:

TABLE 3. RESULTS OF MULTIPLE LOGISTIC REGRESSION ANALYSIS

\begin{tabular}{|c|c|c|c|c|}
\hline Variable & Sig. & $\begin{array}{c}\text { Exp } \\
\text { (B) }\end{array}$ & $\begin{array}{r}95 \\
\text { Lower }\end{array}$ & $\begin{array}{l}\text { o (CI) } \\
\text { Upper }\end{array}$ \\
\hline $\begin{array}{l}\text { Attitudes } \\
\text { toward } \\
\text { HIV/AIDS } \\
\text { transmissi } \\
\text { on through } \\
\text { the use of } \\
\text { syringes }\end{array}$ & 0.026 & 0.091 & 1.423 & 283.583 \\
\hline
\end{tabular}

Table 3 showed the attitudes toward HIV/AIDS transmission through the use of syringes. The value of $\mathrm{OR}=20.091$ showed that good attitudes toward HIV/AIDS transmission through the use of syringes allowed respondents to have positive drop-out 20.091 times compared to bad attitudes.

\section{DISCUSSION}

The study results showed that of 69 respondents most of the respondents had positive drop-out as many as 60 people $(87.0 \%)$ and 9 people $(13.0 \%)$ had negative dropout. 
us to do. Third, attitudes toward behavior together with

This indicated that the behavior of IDUs after no longer following the MMT was good enough since there was only a small proportion who still used drugs.

The study results showed that of 69 respondents, the majority of respondents had good attitudes towards HIV/AIDS transmission through the use of syringes as many as 50 people $(72.5 \%)$ and those who had bad attitudes toward HIV/AIDS transmission through the use of syringes were as many as 19 people $(27.5 \%)$.

The results of the bivariate analysis showed a correlation between respondents' attitudes and the type of drop-out among the participants of Methadone Maintenance Treatment (MMT). It was obtained that respondents who had positive drop-out among respondents who had good attitudes was $98.0 \%$ higher than respondents who had a bad attitude of $57.9 \%$. On the other hand, respondents who had negative drop-out were higher among those who had bad attitudes of $42.1 \%$ compared to those who had good attitudes of $2.0 \%$. Based on the results of statistical tests using the chi square test with a significance level $(\alpha)$ of 0.05 , it was obtained p-value $=0.000$ which meant that there was a correlation between the respondents' attitudes and the type of drop-out among the participants of Methadone Maintenance Treatment (MMT).

The correlation between respondents' attitudes and the type of drop-out among the participants of Methadone Maintenance Treatment (MMT) is in line with Green's (1990) theory, that a person's behavior is influenced by his attitudes. In this case the drop-out behavior of the respondent is influenced by his attitudes toward HIV/AIDS transmission and the correct use of syringe. This is also in line with the theory of reasonable action put forward by Ajzen \& Fishbein (1980) that attitudes influence behavior through a careful and reasoned decision making process. This is also in line with a study conducted by Mulawarman (2009), which stated that one of the factors that had a direct effect on preventive measures or measures to reduce the risk of HIV transmission to injecting drug users was the attitude factor. $6,7,11$

Attitudes become very important especially for expressive behavior. The theory of reasoned action explains that attitude mediate behavior through a careful and reasoned decision making process, and its impact is limited to three things. First, behavior is not much determined by general attitudes but by specific attitudes toward something. Second, behavior is influenced not only by attitudes but also by subjective norms, namely our desire for what others want subjective norms will form an intention or desire to behave in a certain way. ${ }^{12-13}$ Regarding the respondents' answer (we did not attach it), there were some respondents who had bad attitudes according to the researchers. In our opinion, it could occur because the respondents had been already accustomed to such attitudes so it was difficult to change their attitudes even though there was a possibility that the respondents knew it as incorrect attitudes. In addition, there must be a concern in this result that there were still a number of respondents who believed that it was not possible to be infected with HIV/AIDS (20.1\%). This is a wrong attitude since everyone has the potential to be infected with HIV/AIDS, especially they were injecting drug users (IDUs) with a

very high potential to be infected with HIV/AIDS either through syringes or through unprotected sex. Previous study reported that $7.4 \%$ of MMT participants were HIV positive, while other researchers reported the HIV and Hepatitis C co-infection rate of $49.1 \% .^{14,15}$

The limitation of this study was due to it used a cross-sectional design. Thus, it was difficult to determine the cause and effect since the data collection was conducted at the same time.

\section{CONCLUSION}

Attitudes toward HIV/AIDS transmission through the use of syringes obtained $\mathrm{OR}=20.091$, this meant that good attitudes toward HIV/AIDS transmission through the use of syringes allowed respondents to have positive dropout 20.091 times compared to bad attitudes. Recommendation for further study is to analyze the factors that influence attitudes toward HIV/AIDS transmission through the use of syringes, as a consideration in policy planning and program development to improve health services, especially regarding Methadone Maintenance Treatment service.

\section{ACKNOWLEDGMENTS}

This study was supported by the LPDP/Endowment Fund of Education. 
Maintenance Treatment Program (MMTP). Ministry of Health of the Republic of Indonesia. Jakarta. 2010

1. WHO. Data and Statistic on HIV/AIDS. https://www.who.int/hiv/data/en/ Accessed on August 15,2019

2. Ministry of Health of the Republic of Indonesia. Report on the progress of HIV/AIDS \& sexually transmitted infections (STI) in Quarter IV of 2018. Jakarta. Ministry of Health of the Republic of Indonesia. 2019

3. Ministry of Health of the Republic of Indonesia. Health Minister Regulation No.57 Year 2013 concerning Guidelines for Organizing the Methadone Maintenance Treatment

Program. Jakarta. Ministry of Health of the Republic of Indonesia. 2013 4. Robert P. Schwart, Robert K.

Brooner, Ivan D. Montoya, M.D, Marian Currens, Michael Hayes.A 12-Year FollowUp of a Methadone Medical Maintenance Program. The American Journal on Addictions.1999

5. Pham Minh Khue, Nguyen Thi Tham, Dinh Thi Thanh Mai, Pham Van Thuc, Vu Minh Thuc, Pham Van Han et al. A longitudinal and case-control study of dropout among drug users in methadone maintenance treatment in Haiphong, Vietnam. BioMed Central. 2017

6. Lei Zhang, Xia Zou, Di Zhang,

Xiaoling Li, Peizhen Zhao, Li

Ling. Investigation of Repeat

Client Drop-Out and ReEnrolment Cycles in Fourteen Methadone Maintenance

Treatment Clinics in Guangdong, China. PLOS ONE. 2015

7. An Thi Minh Dao, Huong Thi Thu Nguyen, Long Hoang Nguyen. Variation Overtime among Patients of the Six Methadone Maintenance Treatment Clinics in Thai Nguyen from 2011 to 2015. BioMed Research International. 2018

8. Green, W. Lawrence. Health Promotion Planning an Educational \& Environmental Approach. Second edition. Mayfield Publishing Company. 1991

9. Ajzen I, Fishbein M. Understanding Attitudes and Predicting Social Behavior.

Englewood Cliffs, NJ: Prentice-

Hall. 1980

10. Ministry of Health of the Republic of Indonesia. Modules and Curriculum for the Methadone
11. Mulawarman, A, The determinant factor for reducing the risk of HIV transmission to injecting drug users in Makassar. Semarang. 2009

12. Miller JM, Krosnick JA, Holbrook AL, Tahk A, Dionne A. The impact of policy change threat on financial contributions to interest groups. In Explorations in Political Psychology, ed. JA Krosnic, IC Chiang, T Stark. New York: Psychol. Press. In press. 2016

13. Azwar. S. Human Attitudes: Theories and Assessments. Pustaka Pelajar. Yogyakarta. 2011

14. Sheena G. Sullivan, Zunyou Wu, Keming Rou, Lin Pang, Wei Luo, Changhe Wang, et al. Who uses methadone services in China?

Monitoringthe world's largest methadone programme. Addiction. 2014

15. Pu L, Su Y, Wang G, Bai J. Prevalence of HIV and $\mathrm{HCV}$ infections in patients

receiving methadone maintenanc e treatment in Kaiyuan, Yunnan. PudMed.2015 